Bull. Chem. Soc. Ethiop. 2020, 34(1), 25-39.

ISSN 1011-3924

(C) 2020 Chemical Society of Ethiopia and The Authors

Printed in Ethiopia

DOI: https://dx.doi.org/10.4314/bcse.v34i1.3

\title{
SQUARE WAVE ANODIC STRIPPING VOLTAMMETRIC DETERMINATION OF Hg(II) WITH N-p-CHLOROPHENYLCINNAMOHYDROXAMIC ACID MODIFIED CARBON PASTE ELECTRODE
}

\author{
Denekew Alemayehu, Bhagwan Singh Chandravanshi", Tesfu Hailu and Merid Tessema \\ Department of Chemistry, College of Natural Sciences, Addis Ababa University, P.O. Box \\ 1176, Addis Ababa, Ethiopia
}

(Received November 19, 2019; Revised February 11, 2020; Accepted February 29, 2020)

\begin{abstract}
A new method has been developed for the electrochemical determination of $\mathrm{Hg}$ (II) with $\mathrm{N}-p$ chlorophenylcinnamohydroxamic acid (CPCHA) modified carbon paste electrode by square wave anodic stripping voltammetry (SWASV). $\mathrm{Hg}(\mathrm{II})$ was accumulated on the electrode surface by the formation of the complex in an open circuit and the resulting surface was characterized by electrochemical reduction and stripping. The optimum voltammetric response was observed using a carbon paste composition of $7.5 \%(\mathrm{w} / \mathrm{w})$ CPCHA and preconcentration time of $210 \mathrm{~s}$ in $0.1 \mathrm{M}$ sodium acetate at $\mathrm{pH} 8$ followed by electrochemical SWASV in $0.3 \mathrm{M}$ $\mathrm{NH}_{4} \mathrm{Cl}$ solution at $\mathrm{pH} 4$ at a reduction potential of $-0.6 \mathrm{~V}$. The voltammetric signals were linear in the range of 1$25 \mu \mathrm{M} \mathrm{Hg}(\mathrm{II})$ with a detection limit of $12.9 \mathrm{nM}$. The voltammetric response for six replicate measurements of 15 $\mu \mathrm{M} \mathrm{Hg}$ (II) was reproduced with $3.8 \%$ relative standard deviation (RSD). Many coexisting metal ions had little or no effect on the determination of $\mathrm{Hg}(\mathrm{II})$. Five spiked samples of water were evaluated by using the developed method giving recoveries of $\mathrm{Hg}(\mathrm{II})$ in the range $98-105 \%$.
\end{abstract}

KEY WORDS: Chemically modified carbon paste electrode, Square wave anodic stripping voltammetry, $\mathrm{Hg}$ (II) determination, $\mathrm{N}-p$-Chlorophenylcinnamohydroxamic acid, Environmental water samples

\section{INTRODUCTION}

Mercury is one of the most toxic heavy metals that occur in the environment mainly due to industrial applications such as electrical equipment, batteries, paints and extraction of gold from mines and rivers [1]. It can have several effects on human health and living organisms even at very low concentrations, because of its high reactivity, extreme volatility and relative solubility in water and living tissues [2]. Therefore, the determination of mercury is necessary particularly at trace levels.

The analytical techniques which are frequently used for the determination of mercury include inductively coupled plasma-mass spectrometry (ICP-MS) [3], mercury analyzer [4-6], spectrofluorimetry [7], cold vapor-atomic absorption spectrometry (CVAAS) [8], inductively coupled plasma-optical emission spectrometry (ICP-OES) [9], X-ray fluorescence spectrometry (XRF) [10] and graphite furnace atomic absorption spectrometry (GFAAS) [11]. Although these techniques are very reliable and accurate, they have some significant limitations, such as long analysis time and the use of expensive instruments. Furthermore, several complex steps must be performed, and these require specially trained personnel [12]. Electrochemical methods, in particular anodic stripping voltammetry (ASV), is the most favorable technique for the determination of trace level of mercury due to its low cost, simplicity, speed, high sensitivity and the ability to carry out speciation analysis [2].

Chemically modified electrodes (CMEs) have received great attention due to their enhanced sensitivity and selectivity of electrochemical analytical techniques. Several studies showed that chemically modified carbon paste electrode (CMCPE) could be used successfully for the determination of heavy metal ions. For example, carbon paste electrodes modified with

${ }^{*}$ Corresponding author. E-mail: bscv2006@yahoo.com

This work is licensed under the Creative Commons Attribution 4.0 International License 
$\mathrm{SiO}_{2}$ nanoparticles for $\mathrm{Cu}(\mathrm{II})$ and $\mathrm{Cd}(\mathrm{II})$ [13], coconut shell powder for $\mathrm{Cd}(\mathrm{II})$ [14], $\mathrm{CrO}_{3}$ for simultaneous determination of $\mathrm{Cu}(\mathrm{II}), \mathrm{Cd}(\mathrm{II}), \mathrm{Zn}(\mathrm{II}), \mathrm{Pb}(\mathrm{II})$ and $\mathrm{Ag}(\mathrm{I})$ [15] and nitroso-S for $\mathrm{Co}$ (II) [16]. The determination of $\mathrm{Hg}$ (II) has been investigated using CPEs containing variety of modifiers by stripping voltammetry. Modifiers commonly used are EDTA [17], water hyacinth biomass [18], hydroxyapatiten [19], multi-walled carbon nanotubes [20], hybrid mesostructured silica nanoparticles [21], Schiff base [22], silica nanoparticles with Schiff base [23], $\mathrm{SnO}_{2}$ at MWCNTS [24] and organofunctionalised SBA-15 nanostructured silica [25]. Each of these methods has its own advantages and limitations. Mercury exists in most samples, especially in environmental water samples as $\mathrm{Hg}$ (II). Therefore, it is worthwhile to look for new chemically modified electrode with improved quality for the voltammetric determination of $\mathrm{Hg}$ (II) in environmental water samples.

$\mathrm{N}$ - $p$-Chlorophenylcinnamohydroxamic acid (CPCHA) (Scheme 1) has been used as an extracting agent for the spectrophotometric determination of $\mathrm{Ce}(\mathrm{IV})$ [26] and $\mathrm{Nb}(\mathrm{V})$ [27] and as a modifier in carbon paste electrode for the selective and sensitive voltammetric determination of $\mathrm{Co}(\mathrm{II})$ [28], $\mathrm{Pb}$ (II) [29] and $\mathrm{Cd}(\mathrm{II})$ [30] while its analogue $\mathrm{N}$-phenylcinnamohydroxamic acid has been used for the selective and sensitive voltammetric determination of $\mathrm{Cu}$ (II) [31]. However, the complex formation reaction and voltammetric behavior of $\mathrm{Hg}$ (II) by using CPCHA modified carbon paste electrode have not been investigated. Hence the voltammetric behavior of $\mathrm{Hg}(\mathrm{II})$ at $\mathrm{CPCHA}$ modified carbon $\mathrm{CPE}$ was studied in the present investigation.

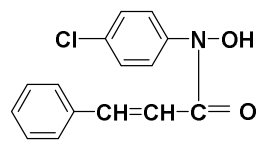

Scheme 1. Structure of N-p-chlorophenylcinnamohydroxamic acid (CPCHA).

The aim of this work was to develop a new CPE modified with CPCHA for the selective preconcentration and determination of $\mathrm{Hg}(\mathrm{II})$ by SWASV. The method has been applied for the determination of traces of $\mathrm{Hg}(\mathrm{II})$ in potable and environmental waters.

\section{EXPERIMENTAL}

\section{Reagents and chemicals}

All the chemicals used were of analytical grade. Graphite powder (spectroscopic grade RBW) was from SGL Carbon (Ringsdorff, Germany) and parafin oil was supplied from (Uvasol, Merck). Anhydrous sodium acetate, acetic acid, sodium hydroxide, ammonium chloride, ammonia solution and hydrochloric acid were obtained from (BDH, England). Standard stock solution of $\mathrm{Hg}(1000 \mathrm{mg} / \mathrm{L}$, atomic absorption standard) was purchased from Sigma-Aldrich (USA). Reagent grade nitrate, sulfate and chloride salts of other cations (Merck and SigmaAldrich) were used as received. Sodium acetate and ammonium chloride solutions of various concentrations were prepared in distilled water. The $\mathrm{pH}$ of sodium acetate and ammonium chloride solutions were adjusted to the desired values by adding acetic acid $(0.1 \mathrm{M})$ or sodium hydroxide $(0.1 \mathrm{M})$ and ammonia solution $(0.1 \mathrm{M})$ or hydrochloric acid $(0.1 \mathrm{M})$, respectively. The working standard solutions, for optimization studies, were prepared daily from the standard stock solution by suitable dilution. N-p-chlorophenylcinnamohydroxamic acid was prepared by the condensation of $\mathrm{N}$ - $p$-chlorophenylhydroxylamine with cinnamoyl chloride at low temperature in diethyl ether medium made alkaline with a saturated solution of sodium bicarbonate [32]. 


\section{Apparatus and instruments}

All the voltammetric experiments for the determination of mercury(II) were performed by using CHI 840C electrochemical analyzer (CH Instruments, USA) connected to IBM Personal computer 130100DX4 for recording of voltammograms and processing of data. All the experiments were carried out using a conventional three electrode system with a UMCPE or CMCPE as a working electrode, a platinum wire as an auxiliary electrode, and a silver/silver chloride $(\mathrm{Ag} / \mathrm{AgCl})$ as a reference electrode. Three different cells $(10 \mathrm{~mL})$ supplied with an electrical spiral stirrers were used for the preconcentration and stripping step. The $\mathrm{pH}$ measurements were carried out using a $\mathrm{pH}$ meter (sensION, SHA Snilu Instruments CO. LTD, China). A magnetic stirrer (Stuart Scientific, Germany) with a Teflon coated stirring bar was used for stirring the solutions. A stop clock (Harris Digitimer, Japan) was employed for time measurement.

\section{Electrode preparation}

Unmodified carbon paste was prepared by adding $0.36 \mathrm{~mL}$ paraffin oil to $1 \mathrm{~g}$ graphite powder. Modified carbon pastes were prepared by substituting corresponding amounts of the graphite powder $(5 \%, 7.5 \%, 10 \%$, and $12.5 \%$ weight-to-weight ratio of the modifier (CPCHA) relative to the graphite powder) and adding the paraffin oil $(0.36 \mathrm{~mL})$ and manually homogenizing the mixture by using mortar and pestle. Both unmodified and modified active pastes were finally pressed into a cavity of the assembly made from $1 \mathrm{~mL}$ plastic syringe of $3 \mathrm{~mm}$ outer diameter with copper wire inserted at one end forming the external electric contact. The electrode surface was polished on clean paper until it had a shiny surface. The fresh electrode was pretreated by using cyclic voltammetry (4-5 runs) in the supporting electrolyte solution to get reproducible results. Renewal of the electrode was done by removing a thin layer of the surface and replacing with a fresh paste.

\section{Procedure}

The CVs were performed at unmodified and modified carbon paste electrodes in the potential range of -1.0 to $1.0 \mathrm{~V}$ (at $100 \mathrm{mV} / \mathrm{s}$ scan rate). All the quantitative measurements were carried out by SWASV. The CMCPE was immersed in a preconcetration cell containing $0.1 \mathrm{M}$ sodium acetate solution $(\mathrm{pH} 8)$ and known amount of $\mathrm{Hg}(\mathrm{II})$ solution with constant stirring (400 rpm) under open circuit for a preselected period of time. The electrode was then taken out from the preconcentration cell, rinsed with distilled water and placed into a stripping cell containing 0.1 $\mathrm{M} \mathrm{NH}_{4} \mathrm{Cl}$ solution ( $\mathrm{pH} 4$ ) as supporting electrolyte. Following the application of a deposition potential of $-0.6 \mathrm{~V}$ (verses $\mathrm{Ag} / \mathrm{AgCl}$ ) for $60 \mathrm{~s}$ without stirring and the electrode was scanned anodically from $-0.6 \mathrm{~V}$ to $0.3 \mathrm{~V}$ after $10 \mathrm{~s}$ equilibration time with pulse amplitude $0.035 \mathrm{~V}$; frequency $15 \mathrm{~Hz}$ and step potential of $0.004 \mathrm{~V}$. After each measurement, the electrode was renewed and pretreated by scanning (4-5 runs) in $0.1 \mathrm{M} \mathrm{NH}_{4} \mathrm{Cl}$ solution. Fresh supporting electrolyte solution was used in each set of experiments to avoid potential build up of $\mathrm{Hg}$ (II) in the electrochemical cell. All electrochemical measurements were made at room temperature (22 $\pm 2{ }^{\circ} \mathrm{C}$ ) under atmospheric conditions (without inert gas bubbling).

\section{Analysis of real samples}

In order to test the practical application of the proposed method, the $\mathrm{Hg}(\mathrm{II})$ content was determined in five different types of water samples (tap water, bottled water, well water, stream water, river water) by spiking method. The well water, stream water, river water samples were filtered before the analysis to remove suspended particles. It was not necessary to filter the tap water and bottled water. Each water sample was spiked with $15 \mu \mathrm{M} \mathrm{Hg}$ (II) and placed in $10 \mathrm{~mL}$ of chemical cell, preconcentrated for $3.5 \mathrm{~min}$ and followed by voltammetric measurements. 


\section{RESULTS AND DISCUSSION}

Voltammetric behavior of $\mathrm{Hg}(I I)$ at CPCHA modified carbon paste electrode

The cyclic voltammetry of unmodified and modified carbon paste electrodes without and with $\mathrm{Hg}(\mathrm{II})$ preconcentration on the electrode surface at open circuit were run in $0.3 \mathrm{M} \mathrm{NH}_{4} \mathrm{Cl}$ at $\mathrm{pH}$ 5. Figure 1 shows the CVs of CPCHA modified electrode with and without $\mathrm{Hg}(\mathrm{II})$ preconcentration. The voltammograms of the unmodified electrode with and without $\mathrm{Hg}(\mathrm{II})$ preconcentration are the same (overlapped curve a) and the CPCHA modified electrode (curve b) without $\mathrm{Hg}(\mathrm{II})$ preconcentration did not show any significant peak in the potential range $-1 \mathrm{~V}$ to $1 \mathrm{~V}$, whereas the $\mathrm{CV}$ of the CPCHA modified electrode with $\mathrm{Hg}(\mathrm{II})$ preconcentration (curve c) shows a well-defined an anodic peak at $0.11 \mathrm{~V}$ and a broad cathodic peak at about $-0.64 \mathrm{~V}$. The anodic peak is due to the oxidation of $\operatorname{Hg}(0)$ to $\mathrm{Hg}(\mathrm{II})$ which formed complex with the CPCHA modifier in the preconcentrating solution while the cathodic peak is due to the reduction of $\mathrm{Hg}(\mathrm{II})$ to $\mathrm{Hg}(0)$. The modified carbon paste electrode also shows a small anodic peak at about $0.69 \mathrm{~V}$ due to the CPCHA modifier. The anodic peak current of $\mathrm{Hg}$ (II) at the CPCHA modified electrode is substantially larger and sharper than the corresponding cathodic peak current. Hence the anodic peak of $\mathrm{Hg}$ (II) was systematically studied by square wave anodic stripping voltammetry for analytical applications.

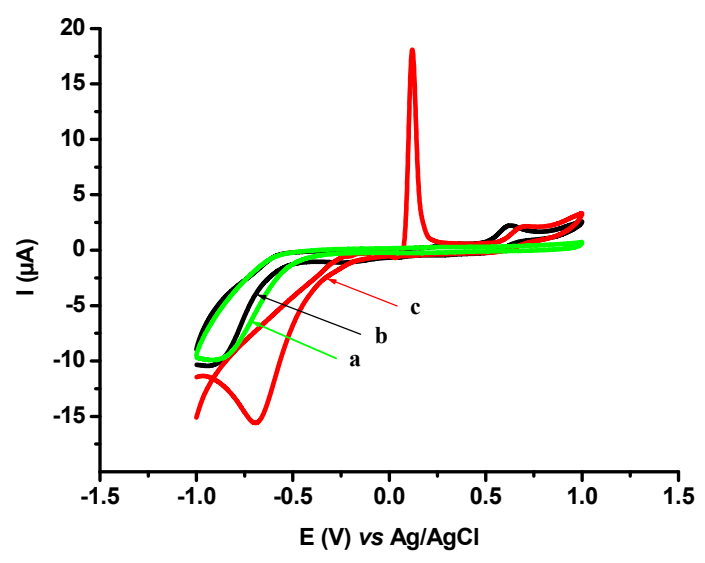

Figure 1. Cyclic voltammograms: (a) bare $\mathrm{CPE}$ with and without $\mathrm{Hg}(\mathrm{II})$ preconcentration, (b) CPCHA modified CPE without $\mathrm{Hg}(\mathrm{II})$ preconcentration and (c) CPCHA modified $\mathrm{CPE}$ with $\mathrm{Hg}(\mathrm{II})$ preconcentration from $0.1 \mathrm{M}$ sodium acetate solution $\mathrm{pH} 10$; preconcentration time: $5 \mathrm{~min}$; $\mathrm{Hg}(\mathrm{II})$ concentration: $100 \mu \mathrm{M}$; supporting electrolyte: $0.3 \mathrm{M} \mathrm{NH}_{4} \mathrm{Cl} \mathrm{pH} 5$; scanned from -1 to $1 \mathrm{~V}$ and back at scan rate: $0.1 \mathrm{~V} / \mathrm{s}$.

The square wave voltammograms of the unmodified and modified carbon paste electrodes were run in the presence of $80 \mu \mathrm{M} \mathrm{Hg}(\mathrm{II})$. As observed in the voltammogram shown in Figure 2, the anodic peak current of $\mathrm{Hg}$ (II) at the CPCHA modified electrode is much larger than that of the unmodified electrode. Furthermore, there is a slight shift in the peak potential of square wave voltammogram of CPCHA modified electrode towards negative potential, which indicates that $\mathrm{Hg}(\mathrm{II})$ is easily oxidized at the CPCHA modified electrode compared to that at unmodified electrode. Therefore, the use of the CPCHA made it possible to significantly improve the analytical signal of the electrode.

Bull. Chem. Soc. Ethiop. 2020, 34(1) 


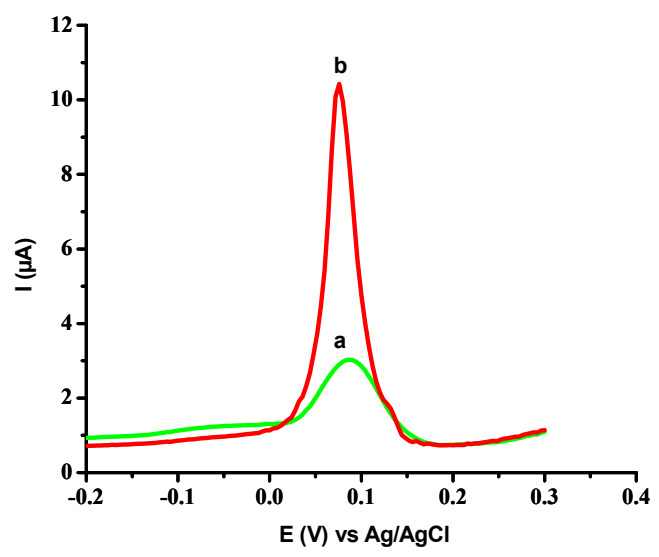

Figure 2. Square wave voltammograms of $80 \mu \mathrm{M} \mathrm{Hg}(\mathrm{II})$ in $0.3 \mathrm{M} \mathrm{NH}_{4} \mathrm{Cl} \mathrm{pH} 4$ at (a) unmodified carbon paste electrode and (b) CPCHA modified carbon paste electrode: preconcentration time $5 \mathrm{~min}$ in $0.1 \mathrm{M} \mathrm{NaAc}$; deposition potential $-0.6 \mathrm{~V}$; deposition time; $60 \mathrm{~s}$ and potential scan from $-0.6 \mathrm{~V}$ to $0.3 \mathrm{~V}$ after $10 \mathrm{~s}$ equilibration time with pulse amplitude $0.025 \mathrm{~V}$, frequency $15 \mathrm{~Hz}$ and step potential $0.004 \mathrm{~V}$.

Even though the modifier, CPCHA, is a water insoluble compound [33], the possibility of its leaching during the voltammetric measurements was tested by its color reaction with V(V) [34] which clearly indicated the absence of CPCHA in the electrolyte solution. Therefore, there was no leaching of the compound during the voltammetric measurements. Leaching was also not observed in the previous voltammetric studies using CPCHA modified electrode [28-30].

\section{Electrochemical processes}

Based on the similar studies reported in the literature [28, 30, 31], the possible electrochemical processes that occur at the modified electrode can be described by the following steps (where HL represents CPCHA):

(1) Preconcentration step (open circuit cell, $0.1 \mathrm{M} \mathrm{NaAc}, \mathrm{pH}$ 8):
$\mathrm{Hg}^{2+}$
$2 \mathrm{HL}$ $\rightarrow$
$\mathrm{HgL}_{2}$ CPE surface
$+$ $2 \mathrm{H}^{+}$
Solution

(2) Reduction step (closed circuit cell, $0.3 \mathrm{M} \mathrm{NH}_{4} \mathrm{Cl}, \mathrm{pH} 4,-0.6 \mathrm{~V}$ ):
$\mathrm{HgL}_{2}+$
$2 \mathrm{H}^{+}+2 \mathrm{e} \rightarrow$
$\mathrm{Hg}^{0}$
$2 \mathrm{HL}$
CPE surface
Solution
CPE surface
CPE surface

(3) Stripping step (closed circuit cell, $0.3 \mathrm{M} \mathrm{NH}_{4} \mathrm{Cl}, \mathrm{pH}$ 4, positive scan: $-0.6 \mathrm{~V}$ to $0.3 \mathrm{~V}$ ):

$\begin{array}{ll}\mathrm{Hg}^{0} \rightarrow & \mathrm{Hg}^{2+}+2 \mathrm{e} \\ \mathrm{CPE} \text { surface } & \text { Solution }\end{array}$

Briefly the accumulation of $\mathrm{Hg}$ (II) on the electrode surface takes place by the complexation of $\mathrm{Hg}(\mathrm{II})$ with the modifier CPCHA in the open circuit cell at $\mathrm{pH}$ 8. The reduction of $\mathrm{Hg}(\mathrm{II})$ in 
the complex $\left(\mathrm{HgL}_{2}\right)$ to $\mathrm{Hg}^{0}$ occurs at an applied potential of $-0.6 \mathrm{~V}$ in closed circuit cell in $0.3 \mathrm{M}$ $\mathrm{NH}_{4} \mathrm{Cl}$ at $\mathrm{pH}$ 4. The stripping of $\mathrm{Hg}^{0}$ occurs after oxidation to $\mathrm{Hg}^{2+}$ on positive scan from $-0.6 \mathrm{~V}$ to $0.3 \mathrm{~V}$ in the closed circuit cell in $0.3 \mathrm{M} \mathrm{NH}_{4} \mathrm{Cl}$, at $\mathrm{pH} 4$.

\section{Effect of amount of CPCHA in the carbon paste}

The accumulation of $\mathrm{Hg}(\mathrm{II})$ at the CPCHA modified $\mathrm{CPE}$ was based on the complex formation reaction between the metal ion, $\mathrm{Hg}(\mathrm{II})$ and the modifier, $\mathrm{CPCHA}$. Therefore, the amount of CPCHA in the carbon paste had significant influence on the voltammetric response of the modified electrode. The effect of the amount of CPCHA in the modified carbon paste electrode was investigated by preparing six different modified carbon paste electrodes $(2.5 \%, 5 \%, 7.5 \%$, $10 \%, 12.5 \%$ and $15 \%$ weight-to-weight ratio of CPCHA to graphite powder in the carbon paste) under identical conditions. The respective peak currents were 1.05, 2.37, 5.34, 4.25, 2.49 and $2.00 \mu \mathrm{A}$. This result clearly indicates that the maximum peak current was obtained with $7.5 \%$ CPCHA in the CPE. Higher amounts of CPCHA containing electrodes gave lower peak currents. This could be related to a decrease in the carbon content of the paste and, consequently, reduction of the conductive electrode area (carbon particles) hampering the electron transfer at the electrode surface. Hence an electrode containing 7.5\% CPCHA was applied for all subsequent experiments.

\section{Effect of composition and concentration of preconcentration solution}

The complex formation reaction of $\mathrm{Hg}(\mathrm{II})$ with CPCHA at the electrode surface and the anodic stripping voltammetric properties of $\mathrm{Hg}$ (II) preconcentration in $\mathrm{NH}_{4} \mathrm{Cl}, \mathrm{NaAc}$ and $\mathrm{Na}_{2} \mathrm{CO}_{3}$ buffer solutions (each one $0.1 \mathrm{M}, \mathrm{pH}$ 8) were investigated. The peak current of $\mathrm{Hg}(\mathrm{II})$ preconcentrated in $\mathrm{Na}_{2} \mathrm{CO}_{3}(3.61 \mu \mathrm{A})$ was slightly smaller than $\mathrm{NaAc}(9.01 \mu \mathrm{A})$. This could be due to the precipitate formation of $\mathrm{Hg}(\mathrm{II})$ as $\mathrm{HgCO}_{3}$ at $\mathrm{pH}$ 8. Preconcentration of $\mathrm{Hg}$ (II) in $\mathrm{NH}_{4} \mathrm{Cl}$ solution showed a much smaller peak current $(1.99 \mu \mathrm{A})$. This is due to complex formation $\mathrm{Hg}(\mathrm{II})$ with ammonia and chloride at high concentration that can hinder the accumulation of $\mathrm{Hg}(\mathrm{II})$ on the electrode surface. Among these, best voltammetric result of $\mathrm{Hg}$ (II) was obtained from preconcentration in NaAc solution.

The effect of NaAc concentration was also tested in the range $0.1-0.5 \mathrm{M}$ at $\mathrm{pH} 8$. The respective peak currents were $9.01,8.70,5.71,2.00$ and $1.00 \mu \mathrm{A}$. This result shows that the maximum peak current of $\mathrm{Hg}$ (II) was obtained from preconcentration in $0.1 \mathrm{M} \mathrm{NaAc}$ solution. It was observed that increasing the concentration of NaAc decreased the peak current. This is due to the formation of a weak complex between acetate ions and $\mathrm{Hg}(\mathrm{II})$. Hence, increasing the concentration of acetate ions decreases the accumulation of $\mathrm{Hg}(\mathrm{II})$ that complexes with CPCHA at the electrode surface. Thus $0.1 \mathrm{M}$ sodium acetate solution was used for preconcentration of $\mathrm{Hg}(\mathrm{II})$ throughout the study.

\section{Effect of $p H$ of preconcentration solution}

The $\mathrm{pH}$ of the preconcentration solution (as shown in the above mechanism) has a direct effect on the complex formation reaction of $\mathrm{Hg}$ (II) with CPCHA. Hence the effect of $\mathrm{pH}$ of the preconcentration solution $(0.1 \mathrm{M} \mathrm{NaAc})$ on the accumulation of $\mathrm{Hg}(\mathrm{II})$ was investigated in the $\mathrm{pH}$ range 5-11. The peak current of CPCHA modified electrode as a function of $\mathrm{pH}$ is shown in Figure 3. The square wave voltammograms at different $\mathrm{pH}$ are shown as inset in Figure 3. It was observed that the peak current increased sharply with increasing $\mathrm{pH}$ from 5 to 8 and then decreased from 9-11. This is due to the increased complex formation of $\mathrm{Hg}$ (II) with CPCHA at the electrode surface with increasing $\mathrm{pH}$ and due to the completion of complex formation $\mathrm{Hg}(\mathrm{II})$ with acetate at higher $(\mathrm{pH}>8)$. Hence $0.1 \mathrm{M}$ sodium acetate $\mathrm{pH} 8$ was used for all subsequent experiments. 


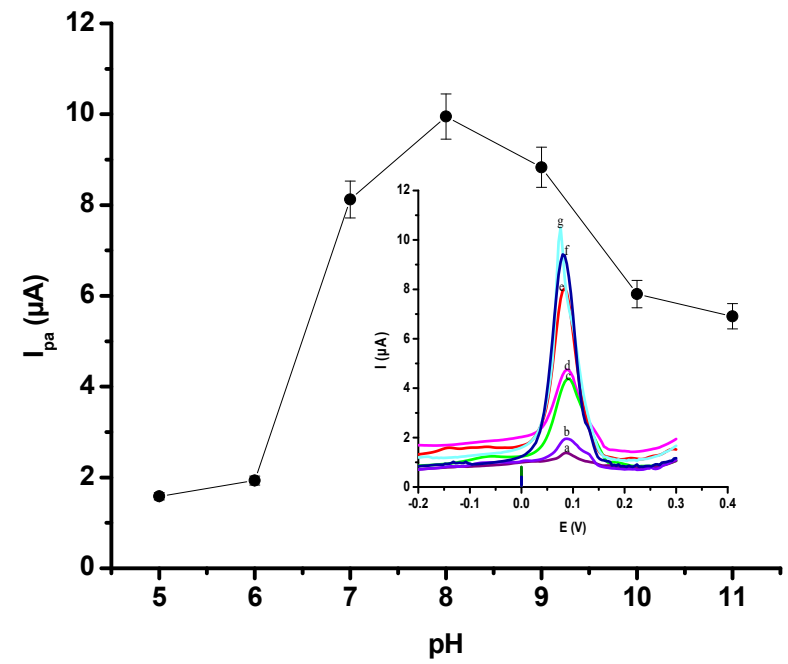

Figure 3. Effect of $\mathrm{pH}$ of preconcentration solution on the square wave anodic stripping voltammetric peak current. Each bar represents mean \pm 3 standard deviation. $\mathrm{Hg}$ (II) concentration: $80 \mu \mathrm{M}$. Other conditions are as in Figure 2. Square wave voltammograms at different $\mathrm{pH}$ as inset (a, $\mathrm{pH} 5$; b, pH 6; c, pH 11; d, pH 10; e, pH 7; f, $\mathrm{pH} 9 ; \mathrm{g}, \mathrm{pH} 8)$.

One would expect the precipitation of $\mathrm{Hg}(\mathrm{II})$ as $\mathrm{Hg}(\mathrm{OH})_{2}$ at such higher pHs. However, this was not observed in this investigation due to the fact that the $\mathrm{Hg}$ (II) solution was spiked into the preconcentration cell just before dipping the electrode in the cell and subsequent stable complex formation of $\mathrm{Hg}$ (II) with CPCHA at the electrode surface. It should also be noted that the acetate ions form weak complexes with $\mathrm{Hg}(\mathrm{II})$ that also prevent the precipitation of $\mathrm{Hg}(\mathrm{OH})_{2}$.

\section{Effects of composition and concentration of supporting electrolyte}

The effect of composition of supporting electrolytes including $\mathrm{H}_{2} \mathrm{SO}_{4}+\mathrm{KCl}, \mathrm{NH}_{2} \mathrm{OH} . \mathrm{HCl}$, $\mathrm{NaH}_{2} \mathrm{PO}_{4}$ and $\mathrm{NH}_{4} \mathrm{Cl}$ buffer solution (each $0.3 \mathrm{M}, \mathrm{pH} 4$ ) were examined. The peak currents were very low in $\mathrm{H}_{2} \mathrm{SO}_{4}+\mathrm{KCl}(2.19 \mu \mathrm{A})$ and $\mathrm{NaH}_{2} \mathrm{PO}_{4}(2.87 \mu \mathrm{A})$. This might be due to the inability of the ions of the two salts to supply hydrogen ions required during the stripping steps (as shown in the above mechanism). While the peak current for $\mathrm{NH}_{2} \mathrm{OH} . \mathrm{HCl}(5.94 \mu \mathrm{A})$ was comparable with that of $\mathrm{NH}_{4} \mathrm{Cl}(6.60 \mu \mathrm{A})$, it has unstable background current. Among these, the electrochemical response in $\mathrm{NH}_{4} \mathrm{Cl}$ solution was the best peak shape, highest stripping peak current, reproducibility and background stability. This might be due to the differences in the extent of providing hydrogen ions required for the reduction step (as shown in the above mechanism) and consequently favoring the proceeding stripping step. Hence, $\mathrm{NH}_{4} \mathrm{Cl}$ buffer solution was selected throughout this study.

The effect of concentration of $\mathrm{NH}_{4} \mathrm{Cl}$ on the peak current was also studied in the range $0.1-$ $0.5 \mathrm{M}$ at $\mathrm{pH}$ 8. The respective peak currents obtained were $2.00,3.10,6.61,2.40$ and $1.11 \mu \mathrm{A}$. This result shows that the concentration of the supporting electrolyte have significant effect on the current response, maximum and reproducible peak current was obtained in $0.3 \mathrm{M} \mathrm{NH}_{4} \mathrm{Cl}$ solution and hence it was selected for the subsequent experiments. 


\section{Effect of pH of supporting electrolyte}

The effect of $\mathrm{pH}$ of the supporting electrolyte $\left(0.3 \mathrm{M} \mathrm{NH}_{4} \mathrm{Cl}\right)$ was also studied by varying the $\mathrm{pH}$ in the range 3-8. The results are shown in Figure 4. Peak current increased with increasing $\mathrm{pH}$ up to $\mathrm{pH}$. This is due to reduction of $\mathrm{Hg}$ (II) at the CME surface involves hydrogen ions (as shown in the above mechanism). The peak current decreased with further increase in the $\mathrm{pH}$ beyond 4 . The increasing $\mathrm{pH}$ hinders the reduction reaction. Maximum peak current was observed at $\mathrm{pH} 4$.

It is evident from the above discussion that the preconcentration and the voltammetric measurement steps require $\mathrm{NaAc}$ and $\mathrm{NH}_{4} \mathrm{Cl}$ solutions of different concentrations and different $\mathrm{pH}$. Hence it was necessary to carry out the preconcentration and the voltammetric measurement separately. Therefore, $0.1 \mathrm{M} \mathrm{NaAc}$ solution of $\mathrm{pH} 8$ and $0.3 \mathrm{M} \mathrm{NH} \mathrm{NH}_{4} \mathrm{Cl}$ solution of $\mathrm{pH} 4$ were used for an open-circuit preconcentration and voltammetric measurements, respectively.

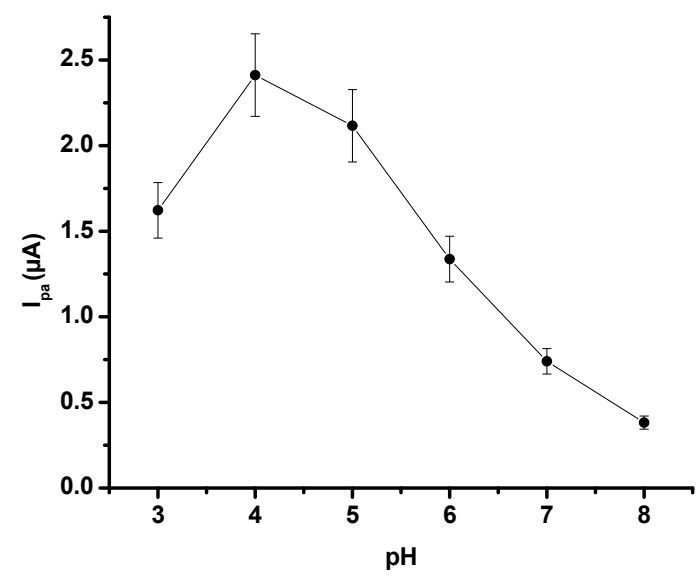

Figure 4. Effect of $\mathrm{pH}$ of supporting electrolyte solution on the square wave anodic stripping voltammetric peak current. Each bar represents mean \pm 3 standard deviation. $\mathrm{Hg}$ (II) concentration: $80 \mu \mathrm{M}$ and other conditions are as in Figure 2.

\section{Effect of preconcentration time}

The other important parameter that affects the voltammetric response is the time allowed for the accumulation of the $\mathrm{Hg}(\mathrm{II})$ from the preconcentration solution at the electrode surface. The effect of accumulation time on the peak current was studied from $30 \mathrm{~s}$ to $300 \mathrm{~s}$. The effect of time on the anodic peak current of the modified electrode is shown in Figure 5. The peak current increases with increasing preconcentration time, indicating an enhancement of $\mathrm{Hg}$ (II) up take at the electrode surface. Normally, the increase in the response continues until a maximum peak current, presumably corresponding to either saturation or an equilibrium surface coverage, is attained. The results obtained indicated attainment of steady-state accumulation levels of $\mathrm{Hg}$ (II) at the electrode surface at exposure times of $210 \mathrm{~s}$. After that there was no further increase in the peak current up to $300 \mathrm{~s}$. Thus, to obtain a linear relationship between $\mathrm{Hg}$ (II) concentration and the peak current, a relatively short preconcentration time must be employed to avoid saturation effect. Therefore, $210 \mathrm{~s}$ preconcentration time was selected throughout this study. 


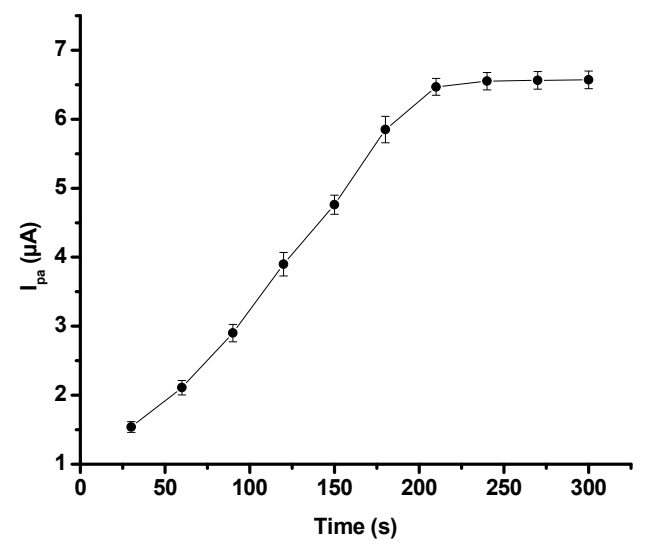

Figure 5. Effect of preconcentration time on the square wave anodic stripping voltammetric peak current. Each bar represents mean \pm 3 standard deviation. $\mathrm{Hg}$ (II) concentration: $80 \mu \mathrm{M}$. Other conditions are as in Figure 2.

\section{Effect of reduction potential and reduction time}

The effect of the reduction potential on the anodic peak current of $\mathrm{Hg}(\mathrm{II})$ was investigated in the range from $-0.2 \mathrm{~V}$ to $-0.8 \mathrm{~V}$. The effect of the reduction potential on the anodic peak current of the modified electrode is shown in Figure 6. At more negative reduction potentials, $\mathrm{Hg}$ (II) is reduced more completely, thus increasing the peak current. The peak current increased as the reduction potential became more negative up to $-0.6 \mathrm{~V}$ and then decreased. At more positive potentials a decrease in the anodic peak current was caused by an inefficient reduction of $\mathrm{Hg}(\mathrm{II})$ to $\mathrm{Hg}(0)$ at the electrode surface. The maximum peak current was obtained at a potential of -0.6 $\mathrm{V}$, providing maximum analytical signal for $\mathrm{Hg}(\mathrm{II})$ determination.

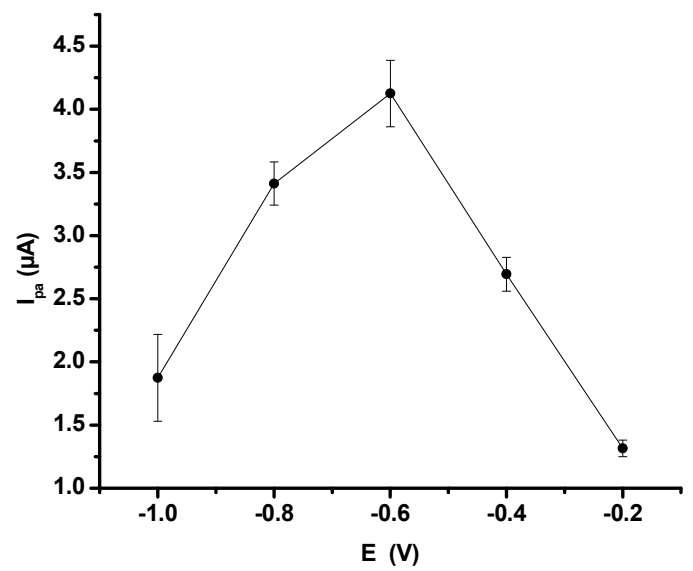

Figure 6. Effect of reduction potential on the SWASV peak current. Each bar represents mean \pm 3 standard deviation. $\mathrm{Hg}(\mathrm{II})$ concentration $80 \mu \mathrm{M}$. Other conditions as in Figure 2.

Bull. Chem. Soc. Ethiop. 2020, 34(1) 
Reduction time is also the most important factor for determination of the detection limit in stripping voltammetric analysis. At the same reduction potential, a longer reduction time will cause $\mathrm{Hg}(\mathrm{II})$ to be reduced completely and consequently lead to a higher peak current. However, when the reduction time is too long the reduced $\operatorname{Hg}(0)$ covers the entire effective electrode surface, and the peak current does not change with increasing reduction time. The effect of the reduction time on the anodic peak current of $\mathrm{Hg}(\mathrm{II})$ was performed at constant reduction potential with different reduction times from 20-80 s. The peak current was found to increase linearly with increasing reduction time up to $60 \mathrm{~s}$ and then remained constant. Therefore $60 \mathrm{~s}$ reduction time was used for all subsequent measurements.

\section{Effect of frequency and amplitude}

In SWASV amplitude and frequency are the most important parameters affecting the shape and sensitivity of the peak current. Effect of amplitude was studied by varying the value from 20 to $50 \mathrm{mV}$. The peak current increased and became broader with increasing amplitude, maximum amplitude of $35 \mathrm{mV}$ was chosen for the study. A similar pattern of the peak current was obtained with increasing the frequency (from 15 to $35 \mathrm{~Hz}$ ). Frequency of $25 \mathrm{~Hz}$ was selected for this work.

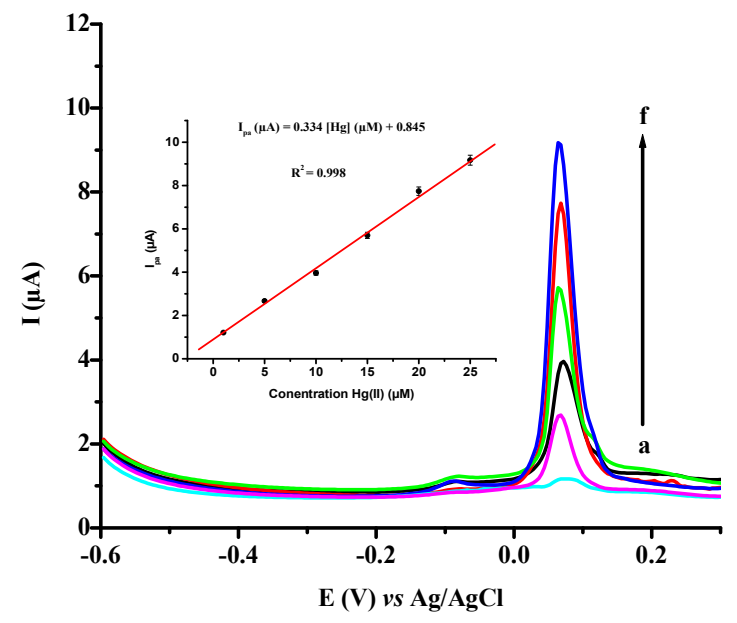

Figure 7. Anodic stripping voltammograms of $\mathrm{Hg}(\mathrm{II})$ at different concentrations (a) 1 ; (b) 5 ; (c) 10; (d) 15 ; (e) 20 and (f) $25 \mu \mathrm{M}$ in $0.3 \mathrm{M} \mathrm{NH}_{4} \mathrm{Cl}$ solution $\mathrm{pH} 4$, preconcentration time 3.5 min with pulse amplitude $0.055 \mathrm{~V}$, frequency $25 \mathrm{~Hz}$ and step potential $0.004 \mathrm{~V}$. Other conditions as in Figure 2.

Calibration curve, detection limit and reproducibility

Under the above optimized conditions, the relationship between the anodic peak current and the $\mathrm{Hg}$ (II) concentration was studied. Well-defined peaks were observed following a $210 \mathrm{~s}$ preconcentration time and reduction potential of - $-0.6 \mathrm{~V}$. Stripping voltammograms and calibration plot for $\mathrm{Hg}(\mathrm{II})$ concentration in the range $1.0 \mu \mathrm{M}$ to $25 \mu \mathrm{M}$ are shown in Figure 7 . The peak current increased with increasing $\mathrm{Hg}(\mathrm{II})$ concentration and a linear calibration plot was obtained with calibration equation: $\mathrm{I}_{\mathrm{P}}=(\mu \mathrm{A})=0.334[\mathrm{Hg}](\mu \mathrm{M})+0.845$ and a correlation coefficient of 0.998 . The detection limit was calculated by $3 \times$ SD of the lowest concentration of 
the linear range $(1.0 \mu \mathrm{M} \mathrm{Hg}(\mathrm{II}))$. The detection limit was found to be $12.9 \mathrm{nM}$. The repeatability and consistency of the proposed electrode was evaluated by six replicate determination of 15 $\mu \mathrm{M} \mathrm{Hg}(\mathrm{II})$. A relative standard deviation (RSD) of $3.83 \%$ was obtained for six repeated measurements of $15 \mu \mathrm{M} \mathrm{Hg}$ (II) solution which demonstrate the good precision of the proposed method.

Comparison of the performance of CPCHA modified carbon paste electrode with other electrodes

The analytical performance of the proposed method was compared with several reported methods in the literature and the results are summarized in Table 1. The results show that the limit of detection obtained in this study was lower or comparable to most of the reported methods in the literature. Some reported methods achieved lower detection limits of $\mathrm{Hg}(\mathrm{II})$, having preconcentration times which are several times longer than that of the present study (210 s). A shorter accumulation time enables faster measurements, therefore in the same duration time more analyses can be made. The proposed method also has good linear range. Thus the proposed method is able to detect the presence of $\mathrm{Hg}(\mathrm{II})$ at trace levels.

Table 1. Comparison of the analytical performance obtained at CPCHA/CPE with different electrodes reported in the literature for the electrochemical determination of $\mathrm{Hg}(\mathrm{II})$.

\begin{tabular}{|l|l|c|c|c|c|}
\hline Electrode type & Technique & $\begin{array}{c}\text { Preconcentration } \\
\text { ime }(\mathrm{min})\end{array}$ & $\begin{array}{c}\text { Liner range } \\
(\mu \mathrm{M})\end{array}$ & $\begin{array}{c}\text { LOD } \\
(\mathrm{nM})\end{array}$ & Ref. \\
\hline${ }^{\mathrm{a}} \mathrm{HA}-\mathrm{NP} / \mathrm{GCE}$ & SWASV & - & $0.20-210$ & 141 & {$[19]$} \\
\hline${ }^{\mathrm{b}} \mathrm{NG} / \mathrm{GCE}$ & DPASV & - & $0.99-8.90$ & 50 & {$[35]$} \\
\hline${ }^{\mathrm{c}} \mathrm{PdO}-\mathrm{NP} / \mathrm{CPE}$ & DPASV & 3 & $0.25-100$ & 19.3 & {$[36]$} \\
\hline${ }^{\mathrm{d}} \mathrm{WBM} / \mathrm{CPE}$ & DPASV & 10 & $1.98-3.96$ & 965 & {$[18]$} \\
\hline${ }^{\mathrm{e}} \mathrm{TCA} / \mathrm{GCE}$ & SWASV & 5 & $0.008-3$ & 5.0 & {$[2]$} \\
\hline${ }^{\mathrm{f}} \mathrm{MTTZ}-\mathrm{MSU}-2 / \mathrm{CPE}$ & DPASV & 5 & $0.1-1$ & 99 & {$[21]$} \\
\hline${ }^{\mathrm{g}} \mathrm{EDTA} / \mathrm{CPE}$ & SWASV & 5 & $50-350$ & 8.6 & {$[17]$} \\
\hline${ }^{\mathrm{h}} \mathrm{MWCNT/CPE}$ & Potentiometry & - & - & 17.8 & {$[20]$} \\
\hline${ }^{\mathrm{i}} \mathrm{L} / \mathrm{CPE}$ & DPV & - & $0.005-5$ & 0.38 & {$[22]$} \\
\hline${ }^{\mathrm{CPCHA} / \mathrm{CPE}}$ & SWASV & 3.5 & $1-25$ & 12.9 & $\begin{array}{c}\text { Present } \\
\text { work }\end{array}$ \\
\hline
\end{tabular}

${ }^{a}$ Hydroxyapatite nanoparticles; ${ }^{b} \mathrm{~N}$-doped grapheme; ${ }^{c}$ palladium oxide supported onto natural phosphate; d water hyacinth biomass; ${ }^{\mathrm{e}} 4$-tertbutyl-1-(ethoxycarbonylmethoxy) thiacalix[4]arene; ${ }^{\mathrm{f}}$ mesostructured silica nanoparticles functionalized with a 5-mercapto-1-methyltetrazole derivative; ${ }^{\mathrm{g}}$ ethylene diamine tetra acetic acid; multi-wall carbon nanotubes; ${ }^{i}$ silica nanoparticles modified by a newly synthesized Schiff base ligand.

\section{Effects of other ions}

CMCPE has significant capability to enhance selectivity because of the modifier-analyte interaction. The selectivity of the CMCPE was evaluated by adding different amounts of other ions (which are commonly present together with $\mathrm{Hg}(\mathrm{II})$ in different samples) into known concentration of $\mathrm{Hg}(\mathrm{II})$ solutions during the preconcentration step, and the results are shown in Table 2. Alkali and alkaline earth metal ions, $\mathrm{NH}_{4}{ }^{+}, \mathrm{Cl}^{-}$and $\mathrm{NO}_{3}{ }^{-}$(up to 100 -fold molar excess); $\mathrm{Ni}(\mathrm{II})$ and $\mathrm{SO}_{4}{ }^{2-}$ (up to 10 -fold molar excess); $\mathrm{Cd}(\mathrm{II})$ and $\mathrm{Co}(\mathrm{II})$ (up to 5-fold molar excess) and $\mathrm{Cu}(\mathrm{II})$ (up to 2 fold) have no significant effect on the determination of $\mathrm{Hg}$ (II). The lower tolerance limit of $\mathrm{Co}$ (II) [28], $\mathrm{Cd}(\mathrm{II})$ [30] and $\mathrm{Cu}$ (II) [31] are due to their complex formation reactions with the CPCHA at the electrode surface in the accumulation medium of $\mathrm{Hg}(\mathrm{II})$ hindering the its accumulation at the electrode surface due to competing complexation. However, equal molar amounts of $\mathrm{Pb}(\mathrm{II})$ and $\mathrm{Fe}(\mathrm{III})$ interfere significantly by decreasing the 
$\mathrm{Hg}(\mathrm{II})$ signal, because both $\mathrm{Pb}$ (II) [29] and $\mathrm{Fe}(\mathrm{III})$ [37] form stable complexes with CPCHA and prevent the complex formation and accumulation of $\mathrm{Hg}(\mathrm{II})$ at the electrode surface.

In general, several ions commonly present in water samples do not interfere in the determination of $\mathrm{Hg}(\mathrm{II})$ and therefore, the sensor is quite selective and can be applied for determination of $\mathrm{Hg}(\mathrm{II})$ in the absence of $\mathrm{Pb}(\mathrm{II})$.

Table 2. Change in SWASV peak current of $15 \times 10^{-6} \mathrm{M} \mathrm{Hg}$ (II) in presence of other ions.

\begin{tabular}{|l|c|c|}
\hline Interfering ion & Concentration (M) & Change in peak current (\%) \\
\hline Alkali and alkaline earth metal ions & $15 \times 10^{-4}$ & $<5$ \\
\hline $\mathrm{NH}_{4}{ }^{-}$ & $15 \times 10^{-4}$ & -1.4 \\
\hline $\mathrm{Cd}(\mathrm{II})$ & $7.5 \times 10^{-5}$ & 1.6 \\
\hline $\mathrm{Co}(\mathrm{II})$ & $7.5 \times 10^{-5}$ & 3.1 \\
\hline $\mathrm{Cu}(\mathrm{II})$ & $3.0 \times 10^{-5}$ & -4.2 \\
\hline $\mathrm{Ni}(\mathrm{II})$ & $1.5 \times 10^{-3}$ & 2.2 \\
\hline $\mathrm{Pb}(\mathrm{II})$ & $15 \times 10^{-6}$ & -42 \\
\hline $\mathrm{Fe}(\mathrm{III})$ & $15 \times 10^{-6}$ & -7.3 \\
\hline $\mathrm{Cl}^{-}$ & $15 \times 10^{-4}$ & -3.5 \\
\hline $\mathrm{SO}_{4}{ }^{2-}$ & $1.5 \times 10^{-4}$ & 1.2 \\
\hline $\mathrm{NO}_{3^{-}}$ & $15 \times 10^{-4}$ & $<5$ \\
\hline
\end{tabular}

\section{Analytical applications}

The applicability and feasibility of the proposed method for the analysis of real samples was assessed by its application to the determination of $\mathrm{Hg}(\mathrm{II})$ in five types of water samples. Tap water, bottled water, well water, stream water and river water samples were employed. The water samples do not require the pretreatment, but they still need to adjust the $\mathrm{pH}$ to 8 using 0.1 $\mathrm{M}$ sodium acetate solution. $\mathrm{Hg}(\mathrm{II})$ was not detected in the tap water, bottled water, well water, and stream water while appreciable concentration $(1.8 \mu \mathrm{M})$ of $\mathrm{Hg}(\mathrm{II})$ was detected and determined in the river water. Recovery of $\mathrm{Hg}(\mathrm{II})$ in water samples were determined by the spiking method. The recovery results are summarized in Table 3. The percentage recoveries were found in the range $98-105 \%$ which are within the acceptable range. Thus the proposed method can be used for the precise and reliable determination of $\mathrm{Hg}(\mathrm{II})$ in environmental water samples.

Table 3. Percentage recovery of $\mathrm{Hg}(\mathrm{II})$ in water samples $(\mathrm{N}=3)$.

\begin{tabular}{|l|c|c|c|c|}
\hline Sample & $\begin{array}{c}\text { Original } \\
(\mu \mathrm{M})\end{array}$ & $\begin{array}{c}\text { Added } \\
(\mu \mathrm{M})\end{array}$ & $\begin{array}{c}\text { Found } \\
(\mu \mathrm{M})\end{array}$ & Recovery (\%) \\
\hline Tap water & ND & 15 & $14.7 \pm 0.17$ & 98.0 \\
\hline Bottled water & ND & 15 & $14.9 \pm 0.12$ & 99.5 \\
\hline Well water & ND & 15 & $14.8 \pm 0.48$ & 98.6 \\
\hline Stream water & ND & 15 & $15.3 \pm 0.22$ & 102 \\
\hline River water & 1.8 & 15 & $17.6 \pm 0.86$ & 105 \\
\hline
\end{tabular}

$\mathrm{ND}=$ Not detected.

\section{CONCLUSION}

A new method has been developed for the square wave anodic stripping voltammetric determination of $\mathrm{Hg}$ (II) using $\mathrm{N}$ - - -chlorophenylcinnamohydroxamic acid modified carbon paste electrode. The method is relatively cheap and easy, and has proved to be a simple and selective for the determination of $\mathrm{Hg}(\mathrm{II})$ at trace level in water samples. The method offers attractive 
properties compared to the previous studies such as simplicity of electrode preparation, high stability, short preconcentration time $(3.5 \mathrm{~min})$, and the use of non-dearated solution. The proposed method has good linear range: $1-25 \mu \mathrm{M} \mathrm{Hg}(\mathrm{II})$ and a lower detection limit: $12.9 \mathrm{nM}$ $\mathrm{Hg}$ (II) than most of the reported methods and not interfered strongly by other ions, which are normally associated with mercury in environmental waters, alloys and complex materials. The developed method has been applied successfully to the determination $\mathrm{Hg}$ (II) in environmental water samples without any prior sample treatment except filtration.

\section{ACKNOWLEDGMENTS}

The authors are thankful to the Department of Chemistry, Addis Ababa University, Addis Ababa, Ethiopia, for providing laboratory facilities. Denekew Alemayehu is thankful to the Department of Chemistry, Addis Ababa University, Addis Ababa, Ethiopia, for sponsoring his study.

\section{REFERENCES}

1. Verestiuc, P.C.; Tucaliuc, O.-M.; Breaban, I.G.; Crețescu, I.; Nemțoi, G. Differential pulse anodic stripping voltammetry for mercury determination. Acta Chem. IASI 2015, 23, 13-24.

2. Wang, F.; Liu, J.; Wu, Y.-J.; Gao, Y.-M.; Huang, X.-F. Anodic stripping voltammetric determination of $\mathrm{Hg}(\mathrm{II})$ in water using a 4-tert-butyl-1-(ethoxycarbonylmethoxy)thiacalix[4]-arene modified glassy carbon electrode. J. Chinese Chem. Soc. 2009, 56, 778-784.

3. Mekonnen, K.N.; Ambushe, A.A.; Chandravanshi, B.S.; Redi-Abshiro, M.; Mccrindle, R.I. Potentially toxic elements in some fresh water bodies in Ethiopia. Toxicol. Environ. Chem. 2012, 94, 1980-1994.

4. Mekonnen, K.N.; Ambushe, A.A.; Chandravanshi, B.S.; Redi-Abshiro, M.; Mccrindle, R.I. Occurrence, distribution and ecological risk assessment of potentially toxic elements in surface sediments of Lake Awassa and Lake Ziway, Ethiopia. J. Environ. Sci. Health, Part A 2015, 50, 90-99.

5. Mekonnen, K.N.; Ambushe, A.A.; Chandravanshi, B.S.; Redi-Abshiro, M.; Mccrindle, R.I.; Panichev, N. Distribution of mercury in the sediments of some freshwater bodies in Ethiopia. Toxicol. Environ. Chem. 2012, 94, 1678-1687.

6. Mekonnen, K.N.; Ambushe, A.A.; Chandravanshi, B.S.; Redi-Abshiro, M.; Mccrindle, R.I. Assessment of potentially toxic elements in Swiss chard and sediment of Akaki River, Ethiopia. Toxicol. Environ. Chem. 2014, 96, 1501-1515.

7. Kim, K.T.; Jung, H.S.; Ahn, J.; Choi, Y.; Jung, J.H.; Park, J. Selective detection of $\mathrm{Hg}^{2+}$ using fluorescent rhodamine-functionalized $\mathrm{Fe}_{3} \mathrm{O}_{4}$ nanoparticles. RSC $A d v$. 2016, 6, 7940579409.

8. Almeida, I.L.S.; Oliveira, M.D.R.; Silva, J.B.B.; Coelho, N.M.M. Suitable extraction of soils and sediments for mercury species and determination combined with the cold vapor generation atomic absorption spectrometry technique. Microchem. J. 2016, 124, 326-330.

9. Lech, T. ICP-OES and CV-AAS in determination of mercury in an unusual fatal case of long-term exposure to elemental mercury in a teenager. Forens. Sci. Int. 2014, 237, e1-e5.

10. Brent, R.N.B.; Wines, H.; Luther, J.; Irving, N.; Joshua Collins, J.; Drake, B.L. Validation of handheld X-ray fluorescence for in situ measurement of mercury in soils. J. Environ. Chem. Eng. 2017, 5, 766-778.

11. Moraes, P.M.; Santos, F.A.; Cavecci, B.; Padilha, C.C.F.; Vieira, J.C.S.; Roldan, P.S.; Padilha, P.M. GFAAS determination of mercury in muscle samples of fish from Amazon, Brazil. Food Chem. 2013, 141, 2614-2617. 
12. Martin-Yerga, D.; Gonzalez-Garcia, M.B.; Costa-Garcia, A. Electrochemical determination of mercury. Talanta 2013, 116, 1091-1104.

13. Afkhami, A.; Soltani-Shahrivar, M.; Ghaedi, H.; Madrakian, T. Construction of modified carbon paste electrode for highly sensitive simultaneous electrochemical determination of trace amounts of copper(II) and cadmium(II). Electroanalysis 2016, 28, 296-303.

14. Rajawat, D.S.; Kumar, N.; Satsangee, S.P. Trace determination of cadmium in water using anodic stripping voltammetry at a carbon paste electrode modified with coconut shell powder. J. Anal. Sci. Technol. 2014, 5, article 19, DOI: 10.1186/s40543-014-0019-0.

15. Koudelkova, Z.; Syrovy, T.; Ambrozova, P.; Moravec, Z.; Kubac, L.; Hynek, D.; Richtera, L.; Adam, V. Determination of zinc, cadmium, lead, copper and silver using a carbon paste electrode and a screen printed electrode modified with chromium(III)oxide. 2017, Sensors, 17, E1832, DOI: 10.3390/s17081832.

16. Mohadesi, A.; Teimoori, E.; Taher, M.A.; Beitollah, H. Adsorptive stripping voltammetric determination of cobalt(II) on the carbon paste electrode. Int. J. Electrochem. Sci. 2011, 6, 301-308.

17. Moutcine, A.; Chtaini, A. Electrochemical determination of trace mercury in water sample using EDTA/CPE modified electrode. Sens. Bio-Sensing Res. 2018, 17, 30-35.

18. Rajawat, D.S.; Srivastava, S.; Satsangee, S.P. Electrochemical determination of mercury at trace levels using water hyacinth biomass modified carbon paste electrode. Int. J. Electrochem. Sci. 2012, 7, 11456-11469.

19. Kanchana, P.; Sudhan,N.; Anandhakumar, S.; Mathiyarasu, J.; Manisankar, P.; Sekar, C. Electrochemical detection of mercury using biosynthesized hydroxyapatite nanoparticles modified glassy carbon electrodes without preconcentration. RSC Adv. 2015, 5, 6858768594.

20. Ali, T.A.; Mohamed, G.G. Multi-walled carbon nanotube and nanosilica chemically modified carbon paste electrodes for the determination of $\mathrm{Hg}(\mathrm{II})$ in polluted water samples. Anal. Methods 2015, 7, 6280-6289.

21. Sanchez, A.; Morante-Zarcero, S.; Perez-Quintanilla, D.; Sierra, I.; Hierro, I. Determination of $\mathrm{Hg}(\mathrm{II})$ in natural waters using a carbon paste electrode modified with hybrid mesostructured silica nanoparticles. Sensor. Actuat. B: Chem. 2012, 163, 38-43.

22. Nourifard, F.; Payehghadr, M. Conductometric studies and application of new Schiff base ligand as carbon paste electrode modifier for mercury and cadmium determination. Int. J. Environ. Anal. Chem. 2016, 96, 552-567.

23. Afkhami, A.; Soltani-Felehgari, F.; Madrakian, T.; Ghaedi, H.; Rezaeivala, M. Fabrication and application of a new modified electrochemical sensor using nano-silica and a newly synthesized Schiff base for simultaneous determination of $\mathrm{Cd}(\mathrm{II}), \mathrm{Cu}(\mathrm{II})$ and $\mathrm{Hg}(\mathrm{II})$. Anal. Chim. Acta 2013, 771, 21-30.

24. Mnyipika, S.H.; Nomngongo, P.N. Square wave anodic stripping voltammetry for simultaneous determination of trace $\mathrm{Hg}(\mathrm{II})$ and $\mathrm{Tl}(\mathrm{I})$ in surface water samples using $\mathrm{SnO}_{2}$ at MWCNTS modified glassy carbon electrode. Int. J. Electrochem. Sci. 2017, 12, 4811-4827.

25. Cesarino, I.; Marino, G.; Matos, J.R.; Cavalheiro, E.T. Evaluation of a carbon paste electrode modified with organofunctionalised SBA-15 nanostructured silica in the simultaneous determination of divalent lead, copper and mercury ions. Talanta 2008, 75, $15-21$.

26. Chandravanshi, B.S.; Gupta, V.K. Extraction and spectrophotometric determination of cerium(IV) with N-p-chlorophenylcinnamohydroxamic acid. Croat. Chem. Acta 1984, 57, 243-249.

27. Wondimu, T.; Chandravanshi, B.S. Extraction and spectrophotometric determination of niobium(V) using N-4-chlorophenylcinnamohydroxamic acid and thiocyanate. Bull. Chem. Soc. Ethiop. 1990, 4, 1-11. 
28. Refera, T.; Chandravanshi, B.S.; Alemu, H. Differential pulse anodic stripping voltammetric determination of cobalt(II) with $\mathrm{N}$ - $p$-chlorophenylcinnamohydroxamic acid modified carbon paste electrode. Electroanalysis 1998, 10, 1038-1042.

29. Degefa, T.H.; Chandravanshi, B.S.; Alemu, H. Differential pulse anodic stripping voltammetric determination of $\mathrm{Pb}(\mathrm{II})$ with $\mathrm{N}$-p-chlorophenylcinnamohydroxamic acid modified carbon paste electrode. Electroanalysis 1999, 11, 1305-1311.

30. Fanta, K.; Chandravanshi, B.S. Differential pulse anodic stripping voltammetric determination of cadmium(II) with $\mathrm{N}$ - $p$-chlorophenylcinnamohydroxamic acid modified carbon paste electrode. Electroanalysis 2001, 13, 484-492.

31. Alemu, H.; Chandravanshi, B.S. Differential pulse anodic stripping voltammetric determination of $\mathrm{Cu}(\mathrm{II})$ with $\mathrm{N}$-phenylcinnamohydroxamic acid modified carbon paste electrode. Anal. Chim. Acta 1998, 368, 165-173

32. Bhura, D.C.; Tandon, S.G. Preparation and properties of N-arylhydroxamic acids. J. Chem. Eng. Data 1969, 14, 278-279.

33. Roshania, R.D.; Agrawal, Y.K. N-p-chlorophenylcinnamohydroxamic acid: A new reagent for the microgram determination of vanadium(V). Microchem. J. 1979, 24, 378-388.

34. Chandravanshi, B.S.; Yenesew, A.; Kebede, Z. Simultaneous determination of iron(III) and vanadium(V) with $\mathrm{N}$-phenylcinnamohydroxamic acid and thiocyanate by extractionspectrophotometry. Anal. Chim. Acta 1985, 172, 175-182.

35. Xing, H.; Xu, J.; Zhu, X.; Duan, X.; Lu, L.; Wang, W.; Zhang, Y.; Yang, T. Highly sensitive simultaneous determination of cadmium(II), lead(II), copper(II), and mercury(II) ions on Ndoped grapheme modified electrode. J. Electroanal. Chem. 2016, 760, 52-60.

36. El Aroui, F.; Lahrich, S.; Farahi, A.; Achak, M.; El Gaini, L.; Manoun, B.; Bakasse, M.; Bouzid, A.; El Mhammedi, M.A. Electrochemical determination of $\mathrm{Hg}$ (II) in ambient water at $\mathrm{PdO}$ /graphite composite electrodes. J. Taiwan Inst. Chem. Eng. 2014, 45, 2725-2732.

37. Amsalu, A.; Chandravanshi, B.S. Extraction and spectrophotometric determination of iron(III) with N-phenylcinnamohydroxamic acid. Mikrochim. Acta 1984, II, 7-15. 